\title{
Bioakumulasi Timbal pada Pengolahan Air Limbah Baterai oleh Acinetobacter sp. IrC2 Menggunakan Biofilter Lekat Diam
}

\section{Bioaccumulation of Lead from Battery Manufacturing Waste Water Treatment by Acinetobacter sp. IrC2 in Fixed Bed Reactor}

\author{
NIDA SOPIAH $^{(1)}$, WAHYU IRAWATI ${ }^{(2)}$ SUSI SULISTIA ${ }^{(1)}$, DAN DJOKO PRASETYO $^{(1)}$ \\ ${ }^{1)}$ Balai Teknologi Pengolahan Air dan Limbah, Teknologi Pengembangan Sumberdaya Alam \\ Gedung 820 Geostech, Kawasan Puspiptek Serpong, Tangerang Selatan, Provinsi Banten, 15314 \\ nidasusetyo@gmail.com \\ ${ }^{2)}$ Program Studi Pendidikan Biologi, Fakultas Ilmu Pendidikan, Universitas Pelita Harapan, Jalan M.H. Thamrin Boulevard 1100, \\ Lippo Karawaci, Tangerang Provinsi Banten, 15811
}

\begin{abstract}
Acinetobacter sp. IrC2 hasmulti-resistance to heavy metals, such as resistant to copper, cadmium, lead, and zinc. The purpose of this research was to study the characterization of Acinetobacter sp. IrC2 in lead bioaccumulation of the battery waste water treated using fixed bed reactor. Eficiency of lead bioaccumulationwas determined by measuring the reducing of lead concentration using atomic absorption spectrophotometer. The results of experiment showed that fluctuated of lead bioaccumulation process in wastewater treated by Acinetobacter $s p$ IrC2 was occurred periodically. Efficincy of lead reducing was occurred at the $28^{\text {th }}$ hours was $86.5 \%$ to $6.31 \mathrm{mg}$ and at the $176^{\text {th }}$ hours was less than $0.01 \mathrm{mg} / \mathrm{L}$. The research showed that Acinetobacter sp. IrC2 was capable of reducing of lead in the battery waste water treated using fixed bed reactor.
\end{abstract}

Keywords: Acinetobacter sp. IrC2, lead, bioaccumulation, Fixed Bed Reactor

ABSTRAK

Acinetobacter sp. IrC2 merupakan bakteri yang memiliki sifat multiresistensi terhadap berbagai logam berat, tembaga, kadmium, timbal dan seng. Penelitian ini dilakukan untuk mempelajari karakterisasi bioakumulasi timbal oleh Acinetobacter sp. IrC2 dalam menyisihkan kadar timbal pada air limbah baterai yang diolah menggunakan biofilter lekat diam bermedia sarang tawon. Efisiensi penyisihan kadar timbal ditentukan dengan berkurangnya kadar timbal menggunakan spektrofotometri serapan atom. Hasil penelitian menunjukkan bahwa proses bioakumulasi timbal mengalami fluktuasi secara berkala dalam air limbah yang diolah Acinetobacter sp IrC2. Efisiensi penyisihan kadar timbal pada jam ke-28 adalah sebesar $86,5 \%(6,31 \mathrm{mg}) / \mathrm{L}$ dan pada jam ke-176 kadar timbal dalam air olahan limbah baterai dalam bioreaktor menjadi kurang dari $0,01 \mathrm{mg} / \mathrm{L}$. Dengan demikian maka Acinetobacter Sp. IrC2 mampu bertindak sebagai agen bioremediasi dalam menyisihkan kadar timbal dalam air limbah baterai dengan menggunakan biofilter lekat diam

Kata kunci: Acinetobacter sp. IrC2, timbal, bioakumulasi, biofilter lekat diam

\section{PENDAhUluan}

Acinetobacter sp. IrC2 merupakan bakteri setempat yang diisolasi dari limbah industri di daerah Rungkut, Surabaya. Hasil penelitian yang telah dilakukan sebelumnya menunjukkan bahwa Acinetobacter sp. IrC2 memiliki resistensi dan kemampuan akumulasi yang tinggi terhadap tembaga $\left(\mathrm{CuSO}_{4}\right)$, Timbal $\left(\mathrm{Pb}\left(\mathrm{NO}_{3}\right)_{2}\right)$, Kadmium $\left(\mathrm{CdSO}_{4}\right)$, seng $\left(\mathrm{ZnSO}_{4} \cdot 7 \mathrm{H}_{2} \mathrm{O}\right)$. Acinetobacter $\mathrm{sp}$. IrC2 juga dapat tumbuh pada medium yang mengandung $1 \mathrm{mM}$ campuran logam berat $\mathrm{CuSO}_{4}, \mathrm{ZnSO}_{4}, \mathrm{~Pb}\left(\mathrm{NO}_{3}\right)_{2}, \mathrm{CdSO}_{4}$ dan dapat mengakumulasi masing-masing logam berat tersebut sebesar $1,50 \mathrm{mg} \mathrm{CuSO}{ }_{4}, 54,57 \mathrm{mg}$ $\mathrm{ZnSO}_{4}, 22,29 \mathrm{mg} \mathrm{Pb}\left(\mathrm{NO}_{3}\right)_{2}$, dan $13,57 \mathrm{mg}$
$\mathrm{CdSO}_{4}$. Acinetobacter sp. IrC2 dapat menurunkan $52,98 \% \quad \mathrm{CuSO}_{4}, 21,65 \% \quad \mathrm{ZnSO}_{4}, 72,01 \% \mathrm{mg}$ $\mathrm{Pb}\left(\mathrm{NO}_{3}\right)_{2}$, dan $11,56 \% \mathrm{CdSO}_{4}$. Acinetobacter sp. IrC2 dapat menurunkan 24,30\% $\mathrm{CuSO}_{4}, 16,38 \%$ $\mathrm{ZnSO}_{4}, \quad 75,93 \% \quad \mathrm{~Pb}\left(\mathrm{NO}_{3}\right)_{2}, \quad 47,62 \% \quad \mathrm{CdSO}_{4}$ di dalam medium yang mengandung $1 \mathrm{mM}$ campuran logam berat tersebut ${ }^{(1)}$. Penelitian lain menunjukkan bahwa pengaruh media kultivasi dapat berpengaruh terhadapa permukaan sel hidrofobik dan kemampuan koagregasi ${ }^{(2)}$.

Bakteri resisten logam berat dapat diisolasi dari lingkungan yang terkontaminasi logam berat dan sangat potensial diterapkan sebagai agen bioremediasi logam berat ${ }^{(3)}$. Populasi bakteri di daerah yang tercemar logam berat akan mengembangkan suatu proses adaptasi untuk 
menjadi resisten terhadap logam berat ${ }^{(4)}$. Salah satu mekanisme resistensi yang dilakukan oleh bakteri terhadap logam berat adalah dengan cara mengakumulasi baik secara aktif (bioakumulasi) maupun secara pasif (biosorbsi) sehingga terjadi penurunan konsentrasi logam berat di lingkungan. Salah satu mekanisme resistensi yang dilakukan oleh bakteri terhadap logam berat adalah dengan cara mengakumulasi baik secara aktif (bioakumulasi) maupun secara pasif (biosorbsi) sehingga terjadi penurunan konsentrasi logam berat di lingkungan ${ }^{(5)}$.

Seeding bakteri dan aklimatisasi bakteri dalam bioreactor merupakan tahap terpenting dalam pengolahan limbah cair. Pada proses seeding dan aklimatisasi diperlukan suatu kondisi lingkungan yang mendukung untuk tumbuh dan berkembangnya bakteri Acinetobacter sp. IrC2 secara optimal, meliputi kebutuhan sumber karbon, nitrogen dan posfor $(100: 5: 1)^{(6)}$. Kebutuhan akan sumber karbon, nitrogen dan posfor ini dapat diperoleh dari kandungan organik yang terdapat dalam limbah atau ditambahkan dari luar. Bila bakteri tersebut sudah dapat beradaptasi ditandai dengan tumbuhnya bakteri berupa lapisan biomassa atau biofilm yang melekat pada permukaan media penyangga, dan ditandai dengan terbentuknya gas. Kecepatan pertumbuhan lapisan biofilm pada permukaan penyangga akan bertambah akibat perkembangbiakan yang terus berlanjut sehingga terjadi proses akumulasi lapisan biomassa yang membentuk lapisan lendir (slime). Di dalam reaktor, bakteri tumbuh melapisi keseluruhan permukaan media dan pada saat beroperasi air limbah akan mengalir melalui celah-celah media dan berhubungan langsung dengan biofilm bakteri $^{(7)}$.

Pada Penelitian ini sebelum dilakukan proses pengolahan air limbah, terlebih dahulu dilakukan proses inokulasi bakteri Acinetobacter sp. IrC2 pada media tumbuh untuk menyiapkan kultur bakteri yang diperlukan dalam proses penyisihan logam timbal dalam air limbah baterai. Dilanjutkan dengan tahapan kultivasi pada bioreaktor lekat diam dan tahap selanjutnya adalah proses penyisihan logam $\mathrm{Pb}$ dalam air limbah baterai.

Penelitian ini dilakukan untuk mempelajari karakterisasi bioakumulasi timbal oleh Acinetobacter sp. IrC2 dalam menyisihkan kadar timbal pada air limbah baterai yang diolah menggunakan biofilter lekat diam bermedia sarang tawon

\section{BAHAN DAN METODE}

\subsection{Kultivasidan Produksi Acinetobacter sp. IrC2}

Kultivasi dilakukan pada medium LuriaBertani (LB) yang mengandung (per liter) : tryptone : $10 \mathrm{~g}$, yeast extract $5 \mathrm{~g}, \mathrm{NaCl} 10 \mathrm{~g}$, dan glukosa 0,1 g.Medium padat dibuat dengan menambahkan 1,5 \% agar bacto. Medium disterilkan dengan menggunakan autoklaf pada suhu $121^{\circ} \mathrm{C}$ dan tekanan $1 \mathrm{~atm}$ selama 15 menit. Stok logam berat terdiri dari: $\mathrm{CuSO}_{4}, \mathrm{~Pb}\left(\mathrm{NO}_{3}\right)_{2}$, $\mathrm{CdSO}_{4}$, dan $\mathrm{ZnSO}_{4} .7 \mathrm{H}_{2} \mathrm{O}$ masing-masing dibuat dengan konsentrasi $1 \mathrm{M}$, sedangkan stok $\mathrm{HgCl}_{2}$ dibuat dengan konsentrasi $0.25 \mathrm{M}$. Stok logam berat disterilkan dengan membran filter $0,2 \mu \mathrm{m}$ dan ditambahkan ke dalam medium LB yang telah disterilkan.

Kultur pemula dibuat dengan menginokulasikan 1 ose biakan agar miring Acinetobacter sp. IrC2 ke dalam medium LB cair kemudian diinkubasikan selama 24 jam pada suhu $37^{\circ} \mathrm{C}$. Pertumbuhan bakteri diukur berdasarkan kekeruhan sel (Optical Density/OD) yang diukur dengan menggunakan alat spektrofotometer pada panjang gelombang 600 $\mathrm{nm}$. Kultur pemula digunakan apabila telah mencapai fase logaritma dengan kekeruhan sel $(\mathrm{OD})=1.0$.

Kultivasi dan produksi bakteri Acinetobacter sp. IrC2, disiapkan sebanyak 10\% dari kapasitas efektif bioreaktor ${ }^{(1)}$.

\subsection{Bioreaktor Lekat Diam (Fixed Bed Reactor)}

Sebelum dilakukan pengolahan air limbah baterai oleh acinetobacter sp. Irc2, beberapa tahap harus dilakukan meliputi: tahap persiapan, tahap pengembang-biakan(Seeding) dan aklimatisasi bakteri Acinetobacter sp. IrC2 serta tahap pengolahan air limbah baterai menggunakan biofilter lekat diam (fixed bed reactor, $F B R$ ).

\section{Tahap Persiapan.}

Pada tahap persiapan unit bioreaktor lekat diam dilakukan kegiatan sebagai berikut: pemasangan pompa, aerator dan sarang tawon pada unit bioreaktor, selanjutnya dilakukan uji kebocoran, pengukuran kapasitas efektif bioreaktor. Bioreaktor yang digunakan dalam penelitian penyisihan logam berat memanfaatkan bakteri Acinetobacter sp. IrC2, terbuat dari bahan akrilik dan media biofilter yang digunakan adalah media dari bahan plastik PVC tipe sarang tawon dengan spesifikasi seperti pada Tabel 1, Gambar 1. Adapun Bioreaktor lekat diam (FBR) secara skematis dijelaskan pada gambar 1 . 
Tabel 1. Spesifikasi media penyangga

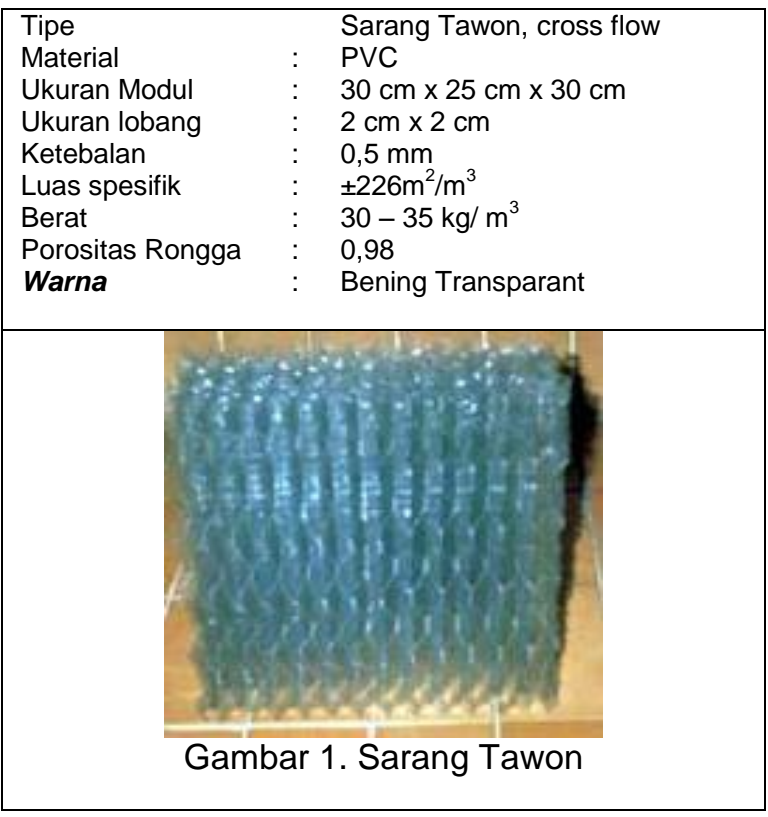

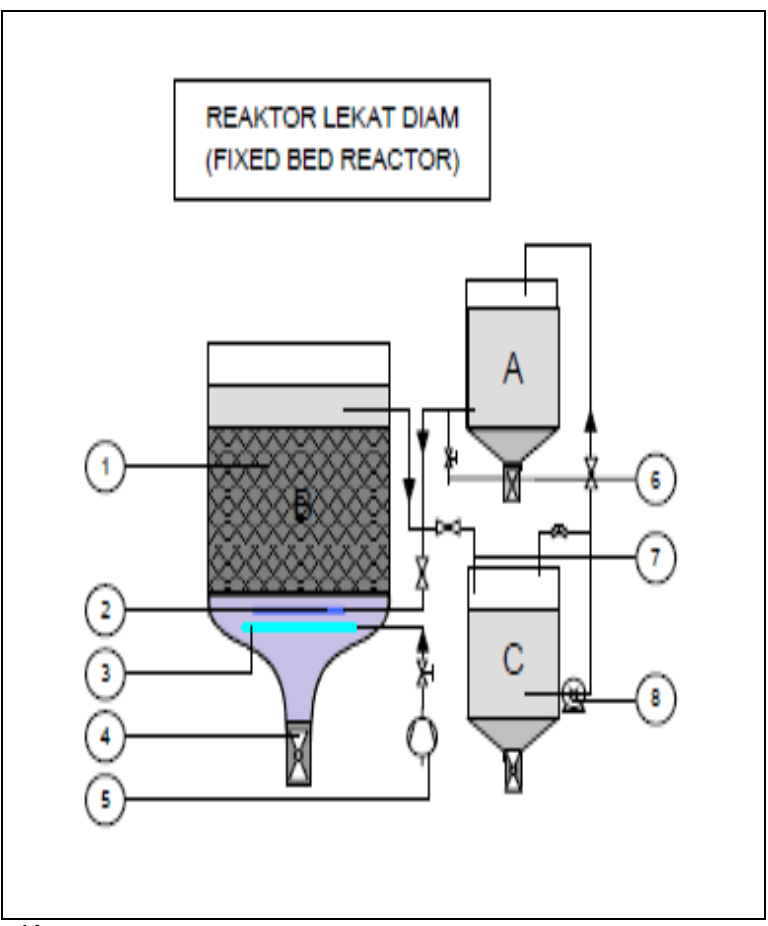

Keterangan:

$\mathrm{A}=$ reaktor umpan, $\mathrm{B}=$ bioreaktor lekat diam (FBR), $\mathrm{C}=$ reaktor penampung, 1 =support material, $2=$ pipa distribusi air limbah, 3=pipa distribusi udara, 4=valve outlet lumpur, 5=compressor udara, 6=titik sampling air umpan (influent),7=titik sampling air olahan (effluent), dan 8=pompa sirkulasi.

\section{Gambar 1. Konstruksi Bioreaktor Lekat Diam (Fixed Bed Reactor)}

Tahap selanjutnya adalah karakterisasi air limbah yang akan diolah dengan melakukan uji laboratorium meliputi pengukuran $\mathrm{pH}$ dengan metoda elektrometri ${ }^{(7)}$, pengukuran Kebutuhan Oksigen Kimiawi (KOK) dengan metode spektrofotometri UV-Vis ${ }^{(8)}$ dan pengukuran logam berat terdiri dari tembaga ${ }^{(9)}$, seng ${ }^{(10)}$, timbal ${ }^{(11)}$, kadmium $^{(12)}$ dengan metode spektrofotometri serapan atom.

Kandungan logam berat yang ada dalam air limbah tersebut selanjutnya dijadikan parameter uji untuk memantau penyisihan kandungan logam berat setelah dilakukan proses remediasi oleh bakteri Acinetobacter sp. IrC2.

Tahap pengembang-biakan(Seeding) dan Aklimatisasi bakteri Acinetobacter sp. IrC2

Proses seeding dilakukan dengan cara mengalirkan air limbah ke dalam reaktor biofilter selama satu minggu dengan waktu tinggal hidrolik (WTH) 2 jam; Selanjutnya air limbah baterai dimasukkan ke dalam bioreaktor secara bertahap.

Tahap pertama air limbah dimasukkan ke dalam bioreaktor sebanyak $10 \% \quad(\mathrm{~V} / \mathrm{V})$, selanjutnya dilakukan pemantauan terhadap penyisihan Kebutuhan Oksigen Kimiawi (KOK) air limbah, bila penyisihan KOKnya lebih dari $50 \%$, selanjutnya penambahan air limbah dinaikkan menjadi 50\% (V/V). Penambahan air limbah dilakukan $100 \%$ bila telah terjadi penyisihan KOK pada hari berikutnya.

Proses aklimatisasi dilakukan untuk mendapatkan suatu kultur bakteri yang stabil dan dapat beradaptasi dengan air limbah yang telah disiapkan. Selama masa aklimatisasi kondisi dalam reaktor dibuat tetap aerob dengan menjaga supply oksigen yang cukup. Aliran udara berasal dari pompa yang disemburkan (spray aerator), penambah udara dilakukan agar proses oksidasinya dapat berjalan dengan sempurna. Media penyangga disiapkan sebagai tempat tumbuh dan melekatnya Acinetobacter sp. IrC2.

Tahap Pengolahan air limbah dengan biofilter lekat diam (fixed bed reactor, FBR)

Pada percobaan ini, bioreaktor dioperasikan dengan cara resirkulasi dengan waktu tinggal hidrolik selama 2 jam. Pada proses pengolahan air limbah baterai dilakukan pengamatan terhadap $\mathrm{pH}$ dan kadar timbal.

\section{HASIL DAN PEMBAHASAN}

Pengolahan limbah secara biologis merupakan salah satu cara penyisihan substrat tertentu yang terkandung dalam limbah cair dengan memanfaatkan aktivitas mikroorganisme untuk melakukan perombakan substrat tersebut.

Pengolahan limbah cair secara biologis, secara umum dapat dibedakan menjadi tiga, yaitu proses biologis dengan biakan tersuspensi 
(suspended culture), biakan melekat (attached culture) dan dengan system kolam (lagoon) ${ }^{(13)}$.

\subsection{PerananAcinetobacter sp. IrC2 sebaga bioakumulator logam berat dalam bioreaktor limbah cair}

\section{Persiapan kultur.}

Kultur bakteri yang dibutuhkan sebagai inokulan bioreaktor adalah dengan populasi sebesar $10^{8}$ jumlah sel yang hidup sehingga dibuat kurva hubungan antara kekeruhan sel (Optical Density/OD) dengan jumlah sel yang hidup (CFU/Colony Form Unit). Kurva hubungan antara kekeruhan sel dan jumlah koloni yang hidup dapat dilihat pada gambar 2. Berdasarkan hasil pengujian yang dilakukan diketahui bahwa waktu terbaik pemanenan bakteri yang akan digunakan sebagai inokulan terjadi pada saat pertumbuhan pada jam ke-6. Pada saat tersebut bakteri mencapai $\mathrm{OD}=0.6$ dengan jumlah koloni $12 \times 10^{8}$. Selanjutnya kultur inokulan bioeaktor selalu dipanen pada jam ke- 6 dengan OD sekitar 0.6 karena pada saat itu bakteri mengalami pertumbuhan yang paling baik.
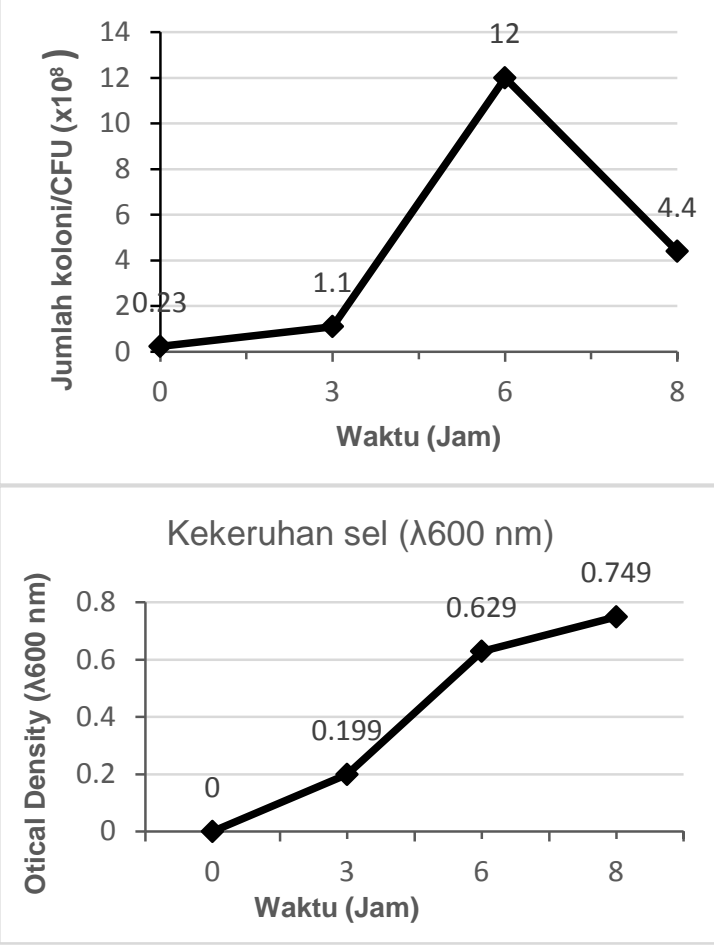

Gambar 2. Kurva pertumbuhan bakteri yang diukur dengan mengamati kekeruhan sel dan pembentukan koloni pada medium agar.

\subsection{Pengaruh pH terhadap Populasi Bakteri Acinetobacter sp. IrC2}

Pertumbuhan bakteri merupakan salah satu faktor yang harus diperhatikan dalam proses pengolahan limbah. Salah satu faktor yang berpengaruh terhadap pertumbuhan bakteri adalah $\mathrm{pH}$.

Pengaruh $\mathrm{pH}$ terhadap pertumbuhan bakteri ini berkaitan dengan aktivitas enzim. Enzim ini dibutuhkan oleh beberapa bakteri untuk mengkatalis reaksi-reaksi yang berhubungan dengan pertumbuhan bakteri. Apabila $\mathrm{pH}$ dalam suatu medium atau lingkungan tidak optimal maka akan mengganggu kerja enzim-enzim tersebut dan akhirnya mengganggu pertumbuhan bakteri itu sendiri ${ }^{(14)}$. Nilai $\mathrm{pH}$ merupakan faktor yang mempengaruhi aktivitas enzim, dimana aktivitas enzim ini akan maksimum pada kondisi $\mathrm{pH}$ optimum.

Bila $\mathrm{pH}$ lingkungan tidak sesuai untuk aktivitas enzim secara optimal, maka bakteri tidak dapat melakukan metabolisme dengan baik. Akibatnya bakteri tidak dapat tumbuh dengan optimal. Berdasarkan $\mathrm{pH}$, bakteri dikelompokkan menjadi golongan asidofil (bakteri yang tumbuh dengan baik pada $\mathrm{pH}$ asam), netral (bakteri yang tumbuh dengan baikpada $\mathrm{pH}$ netral) dan alkalifil (bakteri yang tumbuh dengan baik pada $\mathrm{pH}$ basa). Kisaran $\mathrm{pH}$ untuk pertumbuhan setiap kelompok bakteri sangat bervariasi. Beberapa bakteri mampu tumbuh pada kisaran $\mathrm{pH}$ yang lebar. Pada penelitian ini, dilakukan pengamatan terhadap pengaruh $\mathrm{pH}$ dengan rentang 4-8 terhadap laju pertumbuhan bakteri Acinetobacter sp. IrC2

Hasil penelitian menunjukkan bahwa laju pertumbuhan Acinetobacter sp. IrC2 dipengaruhi oleh nilai $\mathrm{pH}$ dari medium, Hasil uji pH optimum yang memungkinkan pertumbuhan bakteri dapat tumbuh dengan baik pada kisaran $\mathrm{pH} 5-\mathrm{pH} 8$ sehingga apabila $\mathrm{pH}$ limbah terdapat pada kisaran tersebut berarti isolat bakteri dapat tumbuh dengan baik sedangkan pada $\mathrm{pH} 4$ Acinetobacter sp. IrC2 tidak memperlihatkan aktivitas pertumbuhan (gambar 3).

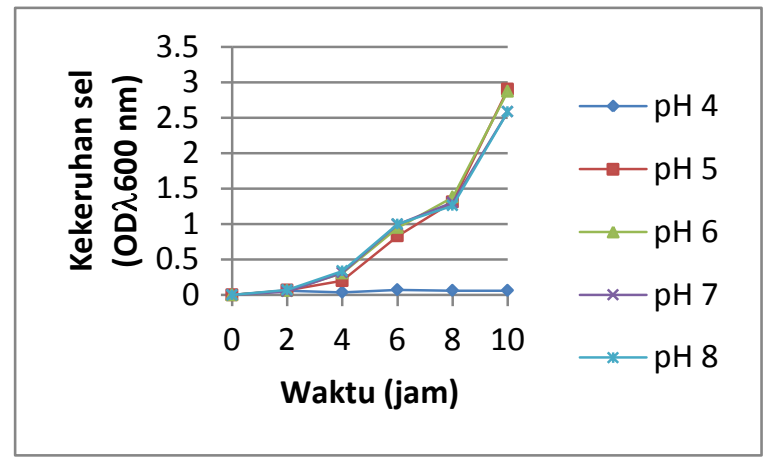

Gambar 3. Pengaruh $\mathrm{pH}$ terhadap pertumbuhan bakteri

\subsection{Inokulasi Bakteri ke dalamBioreaktor.}

Bioreaktor adalah suatu alat pengolahan limbah secara biologis dengan menggunakan 
suatu media penyangga (support material) yang berfungsi sebagai tempat pertumbuhan bakteri. Pertumbuhan bakteri ditandai dengan terbentuknya lapisan biofilm pada permukaan media penyangga. Reaktor dengan sistem pertumbuhan melekat diciptakan agar mendapatkan konsentrasi bakteri yang tinggi. Material penyangga dapat dibuat dari berbagai bahan yang tidak terdegradasi seperti plastik, keramik, tanah liat, batu apung, atau ijuk ${ }^{(15)}$.

Pada saat baru dipasang, media biofilter belum tampak adanyabakteri yang menempel pada permukaan media sarang tawon. Setelah proses pengembangbiakan (seeding) bakteri Acinetobacter sp. IrC2 berjalan selama seminggu tampak tumbuh lapisan yang melekat pada permukaan media zona aerob yaitu terbentuknya lapisan tipis berwarna kecoklat-coklatan. Inokulasi dilakukan dengan menambahkan 10\% kultur bakteri ke dalam bioreaktor yang berisi limbah (Gambar 4).

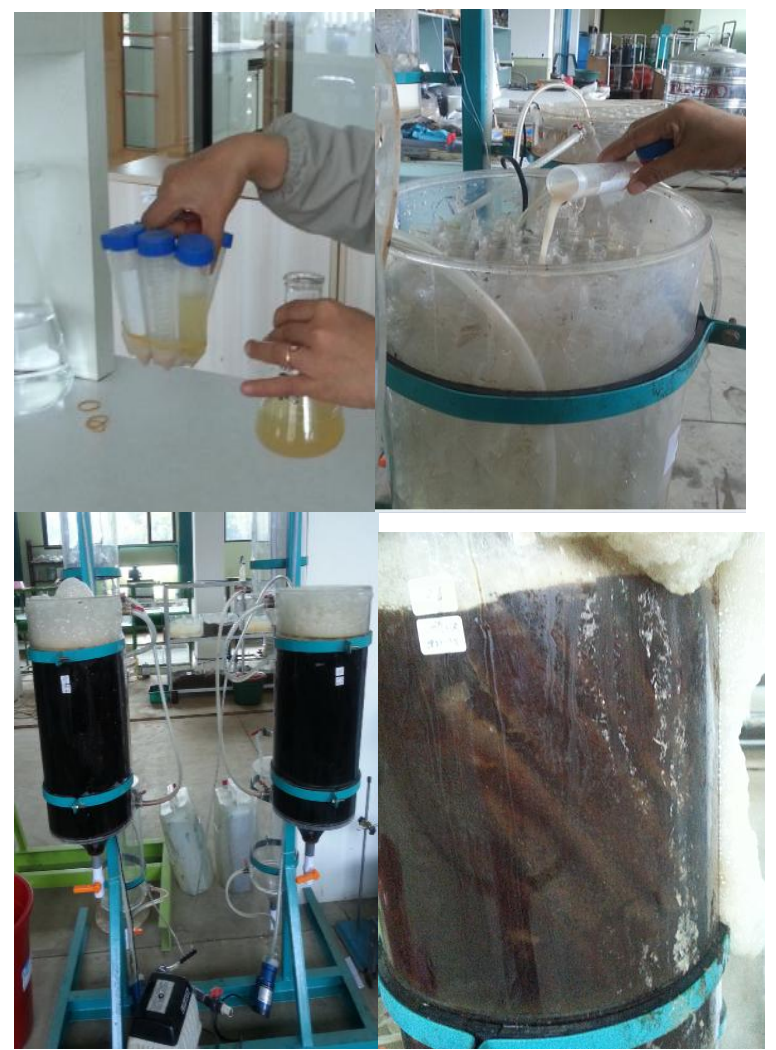

Gambar 4. Seeding bakteri hari ke-7, tampak terbentuk lapisan berwarna kecoklatcoklatan.

Dalam proses pengembangbiakan (seeding) bakteri Acinetobacter sp. IrC2 dilakukan dengan penambahan sumber karbon menggunakan molase $3 \%$. Pemanfaatan molase sebagai substrat dan media tumbuh yang baik untuk bakteri disebabkan karena molase merupakansumber karbon, nitrogen juga vitamin dan elemen yang dimanfaatkan sebagai substrat yang murah ${ }^{(16,17)}$.

Tabel 2. Komposisi kimia molase ${ }^{(16)}$

\begin{tabular}{ll}
\hline Kandungan kimia & Berat/gram \\
\hline Sukrosa & 33,4 \\
Gula invert & 21,2 \\
Nitrogen & 19,6 \\
$\mathrm{P}_{2} \mathrm{O}_{5}$ & $0,4-1,5$ \\
Kalsium oksida & $0,6-2,0$ \\
$\mathrm{MgO}$ & $0,1-1,1$ \\
$\mathrm{~K} \mathrm{O}$ & $0,03-0,1$ \\
$\mathrm{Abu}$ & $7-11$ \\
Berat kering & $77-84$ \\
Thiamin & $830 \mathrm{mg} / 100 \mathrm{~g}$ \\
Riboflavin & $250 \mathrm{mg} / 100 \mathrm{~g}$ \\
Piridoksin & $650 \mathrm{mg} / 100 \mathrm{~g}$ \\
Niacin Amida & $2100 \mathrm{mg} / 100 \mathrm{~g}$ \\
Asam pantotenat & $2140 \mathrm{mg} / 100 \mathrm{~g}$ \\
Asam folat & $3,8 \mathrm{mg} / 100 \mathrm{~g}$ \\
Biotin & $120,0 \mathrm{mg} / 100 \mathrm{~g}$ \\
\hline
\end{tabular}

Dari hasil seeding bakteri tersebut, tampak bakteri Acinetobacter sp. IrC2 dapat beradaptasi dengan limbah artificial yang telah diberi umpan air limbah sebanyak 10\%, dengan indikasi terbentuknya biosurfaktan berupa buih yang dihasilkan dari proses aktivitas bakteri Acinetobacter sp. IrC2.

Selain kebutuhan nutrisi dipantau juga terhadap nilai $\mathrm{pH}$ air limbah, karena $\mathrm{pH}$ yang terlalu asam maupun basa akan berpengaruh terhadap pertumbuhan maupun aktivitas bakteri.

$\mathrm{pH}$ limbah baterai awal mempunyai sifat asam yang ditunjukkan dengan nilai $\mathrm{pH}$ yang rendah yaitu sebesar 1,55. Agar bakteri dapat tumbuh dan bekerja dengan baik perlu dilakukan netralisasi dengan larutan basa. Pada penelitian untuk menaikkan $\mathrm{pH}$ air limbah dilakukan penambahan dengan $\mathrm{Na}_{2} \mathrm{CO}_{3} 1 \mathrm{~N}$. Berikut grafik pemantauan $\mathrm{pH}$ selama proses pengolahan limbah baterai.

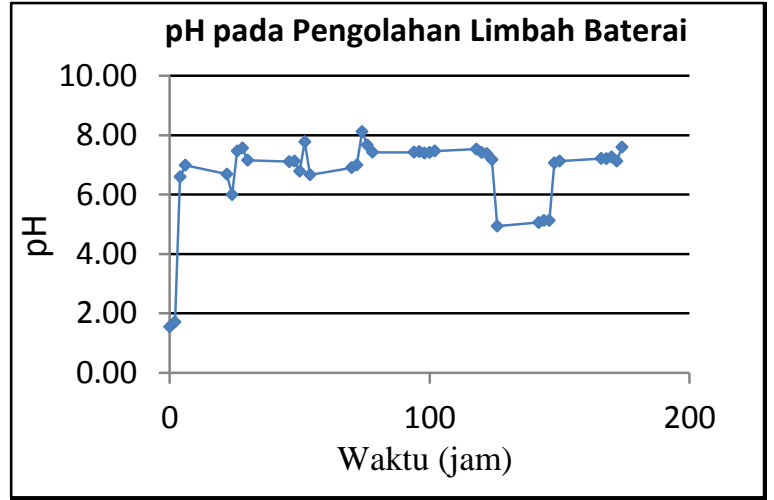

Gambar 6. Grafik pH air limbah selama proses pengolahan limbah baterai pada berbagai waktu 


\subsection{Pengolahan Limbah baterai menggunakan bioreaktor lekat diam (Fixed Bed Reactor)}

Penelitian sebelumnya terkait pengolahan limbah dalam menghilangkan timbal menggunakan bioreaktor lekat diam telah dilakukan oleh beberapa peneliti sebelumnya seperti Kumar dan Acharya menggunakan sekam padi yang diperkaya dengan natrium karbonat $(\mathrm{NCRH}){ }^{(18)}$. Dari hasil kajiannya terhadap kinerja adsorben (NCRH) dalam menghilangkan timbal, ditemukan bahwa bahan adsorben tersebut merupakan media yang efektif untuk menghilangkan timbal secara kontinyu menggunakan bioreaktor lekat diam.

Nwabanne dan Igbokwe, mengkaji kinerja adsorpsi bioreaktor lekat diam untuk menghilangkan $\mathrm{Pb}(\mathrm{II})$ menggunakan sabut kelapa sawit ${ }^{(19)}$, mereka mempelajari pengaruh parameter penting seperti konsentrasi inlet, laju alir dan tinggi kolom terhadap kurva terobosan dan kinerja adsorpsi. Diamati bahwa tinggi kolom sangat berpengaruh terhadap kinerja adsorpsi terhadap timbal.

Pada penelitian ini untuk melihat kinerja bakteri Acinetobacter sp. IrC2 dalam bioreaktor lekat diam menggunakan media dari bahan plastik PVC tipe sarang tawon, pemantauan dilakukan terhadap menurunnya nilai KOK sebelum dan sesudah proses pengolahan. Bila terjadi penurunan pada nilai KOK, ini menunjukkan bahwa terjadi aktivitas bakteri dalam mendegradasi limbah organik yang ada dalam limbah, sedangkan bila proses degradasi tidak terjadi menunjukkan bahwa Acinetobacter sp. IrC2 tidak mampu beradaptasi dan mendegradasi limbah tersebut.

Dari hasil pengamatan yang dilakukan terjadi pola yang berfluktuasi terhadap penyisihan nilai $\mathrm{KOK}$, hal ini terjadi karena penambahan beban organik pada pengolahan air limbah disebabkan adanya fase kematian pada siklus kehidupan bakteri sehingga meningkatkan kandungan organik di dalam limbah tersebut. Selain terjadinya fase kematian, bakteri juga mengalami fase pertumbuhan, yang menyebabkan jumlah populasi bakteri dalam air limbah bertambah dan mampu meningkatkan proses degradasi organik yang ditunjukkan dengan terjadinya penurunan nilai KOK dalam bioreaktor. Berikut grafik penyisihan KOK (mg/L) yang diukur pada waktu yang telah ditetapkan, yaitu jam 08.05; 10.05; 12.05; 14.05 dan 16.05 (Gambar 7).

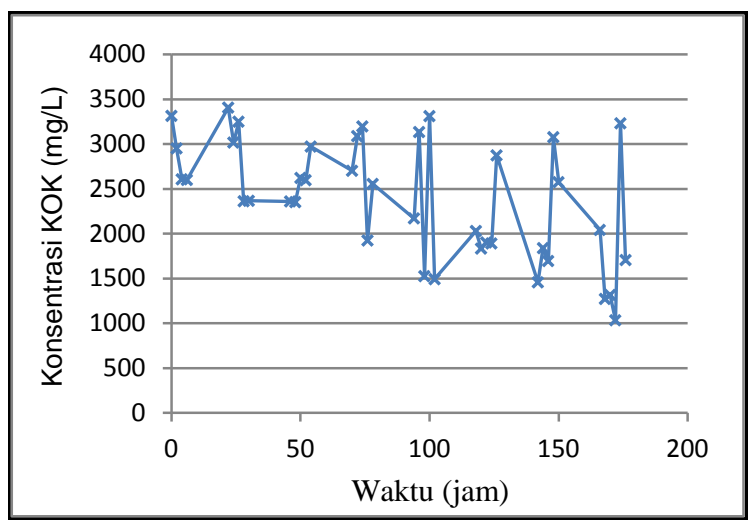

Gambar 7. Grafik kompilasi penyisihan KOK ( $\mathrm{mg} / \mathrm{L})$ pengolahan limbah baterai menggunakan bioreaktor lekat diam (Fixed Bed Reactor)

Ketika derajat pertumbuhan bakteri telah menghasilkan populasi yang maksimum, maka akan terjadi keseimbangan antara jumlah sel yang mati dan jumlah sel yang hidup. Fase stasioner terjadi pada saat laju pertumbuhan bakteri sama dengan laju kematiannya, sehingga jumlah bakteri keseluruhan bakteri akan tetap. Keseimbangan jumlah keseluruhan bakteri ini terjadi karena adanya pengurangan derajat pembelahan sel. Hal ini disebabkan oleh kadar nutrisi yang berkurang dan terjadi akumulasi produk toksik sehingga menggangu pembelahan sel. Fase kematian yang ditandai dengan peningkatan laju kematian yang melampaui laju pertumbuhan, sehingga secara keseluruhan terjadi penurunan populasi bakteri ${ }^{(20)}$.

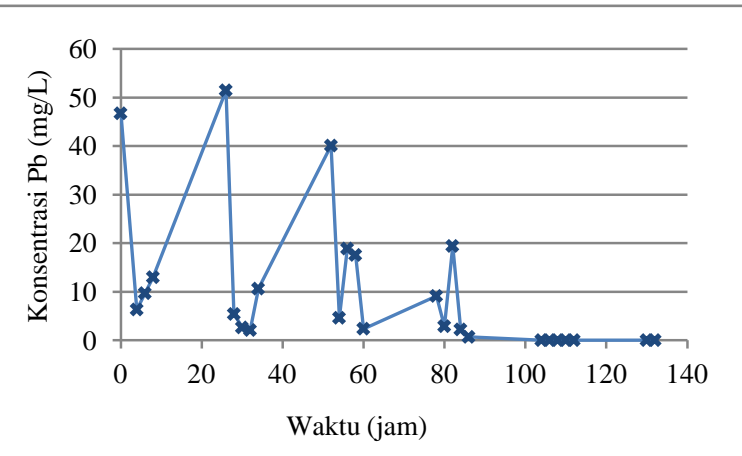

Gambar 8. Grafik penyisihan $\mathrm{Pb}$ (mg/L) pada pengolahan limbah baterai menggunakan bioreaktor lekat diam (Fixed Bed Reactor)

Pada pengolahan limbah baterai menggunakan bioreaktor lekat diam (Fixed Bed Reactor) selama 8 hari, terjadi fluktuasi proses penyisihan logam timbal dalam air limbah oleh Acinetobacter sp. IrC2. Proses penyisihan logam timbal secara signifikan terjadi pada jam ke-28, penyisihan timbal mencapai $86,5 \%$; Proses penyisihan timbal mengalami penurunan kembali sampai pada jam ke-50, dan mengalami 
kenaikan kembali penyisihannya pada jam ke-56 sebesar $95,5 \%$ menjadi 2,08 mg/L. Peningkatan kembali konsentrasi logam timbal di dalam air olahan terjadi pada jam ke-58 menjadi 10,62 $\mathrm{mg} / \mathrm{L}(77,3 \%)$ dan pada jam ke 76 terjadi peningkatan logam timbal 40,08 $\mathrm{mg} / \mathrm{L}(14,2 \%)$. Pada jam ke-78 penyisihan logam timbal terjadi kembali menjadi 4,6 mg/L $(90,2 \%)$, dan pada jam ke-80 terjadi peningkatan kembali konsentrasi logam timbal menjadi $18,87 \mathrm{mg} / \mathrm{L} \quad(59,6 \%)$, peningkatan efiiensi meningkat kembali sampai jam ke 84 yaitu menjadi $2,36 \mathrm{mg} / \mathrm{L}$ dan jam ke 176 konsentrasi logam $\mathrm{Pb}$ dalam air olahan limbah baterai dalam bioreaktor mampu menyisihkan $\mathrm{Pb}$ menjadi $<0,01 \mathrm{mg} / \mathrm{L}$ (Gambar 8).

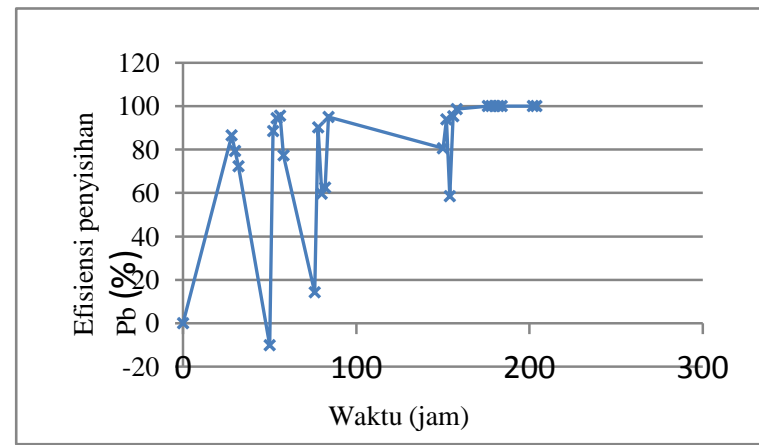

Gambar 9. Grafik Efisiensi penyisihan $\mathrm{Pb}(\%)$ pada pengolahan limbah baterai menggunakan bioreaktor lekat diam (Fixed Bed Reactor).

\section{KESIMPULAN}

Acinetobacter sp. IrC2yang ditumbuhkan pada biofilter lekat diam bermedia sarang tawonmampu menyisihkan timbal terlarut dalam limbah baterai.Fluktuasi proses penyisihan kadar timbal dalam air limbah oleh Acinetobacter sp. IrC2 terjadi selama proses bioakumulasi timbal selama 8 hari

Proses penyisihan logam timbal terjadi pada jam ke-28 adalah sebesar $86,5 \%(6,31 \mathrm{mg}) / \mathrm{L})$, dan efisiensi penyisihan meningkat pada jam ke56 menjadi 95,5\% (2,08 mg/L), dan pada jam ke176 kadar timbal dalam air olahan limbah baterai dalam bioreaktor menjadi $<0,01 \mathrm{mg} / \mathrm{L}$.

\section{PERSANTUNAN}

Penelitian ini didanai oleh Kemenristek-Dikti dalam Proyek Hibah Bersaing 2015. Ucapan terima kasih disampaikan kepada Bapak Arie Herlambang yang telah medukung terlaksananya kegiatan penelitian ini juga kepada Bapak Suherman, Bapak Fajar dan Bapak Sopyan yang telah membantu terlaksananya penelitian ini serta Universitas Pelita Harapan atas kerjasama Penelitian yang telah dirintis selama ini.

\section{DAFTAR PUSTAKA}

1. Irawati,W., L:. Kusumawati, N. Sopiah, (2015), The Potency of Acinetobacter sp. IrC2 Isolated from Industrial Wastewater Treatment Plant in Rungkut-Surabaya As a Bioremediation Agent for Heavy Metals, Asian Journal of Microbiology, Biotechnology \& Environmental Science17(2): 357-363

2. Malik A., P. Kimchhayarasy., S. Takanori, O. Masamitsu, K.Kazuo, (2004), Effect of cultivation time and growth medium on the coaggregation capability of Acinetobacter johnsonii S35, World Journal of Microbiology and Biotechnology 20:781-786

3. Zeyaulah M.D., B. Isla, A. Ali, (2010). Isolation, identification, and PCR amplification of merA gene from highly mercury polluted Yamuna River. Afr $J$ of Biotechnol. 9: 3510-3515.

4. Leung W.C, H. Chua, W. Lo, (2001), Biosorption of Heavy Metals by Bacteria Isolated from Activated Sludge. Appl Biochem Biotech. 91-93: 171-84

5. Johncy M, B. Hemambika, J. Hemapriya, and V. Ajesh-Kannan., (2010), Comparative Assessment of Heavy Metal Removal by immobilized and dead bacterial cells: A biosorption approach. Afr $J$ of Environ Sci and Tech. 4: 077-083.

6. Benefield, L.D and C.W. Randall, (1980), Biological process Design for Wastewater Treatment. Prentice Hall Inc., Englewood Cliffs

7. Anonim, (2004), Air dan air limbah - Bagian 11: Cara uji derajat keasaman $(\mathrm{pH})$ dengan menggunakan alat $\mathrm{pH}$ meter, SNI 6989.11: 2004

8. Anonim, (2009), Air dan air limbah - Bagian 2: Cara uji Kebutuhan Oksigen Kimiawi (Chemical Oxygen Demand, COD) dengan refluks tertutup secara spektrofotometri, SNI 6989.2: 2009

9. Anonim, (2009), Air dan air limbah - Bagian 6: Cara uji tembaga (Cu) secara Spektrofotometri Serapan Atom (SSA) nyala, SNI 6989.6: 2009

10. Anonim, (2009), Air dan air limbah - Bagian 7: Cara uji seng (Zn) secara Spektrofotometri Serapan Atom (SSA) - nyala, SNI 6989.7: 2009

11. Anonim, (2009), Air dan air limbah - Bagian 8: Cara uji timbal $(\mathrm{Pb})$ secara Spektrofotometri Serapan Atom (SSA) nyala, SNI 6989.8: 2009 
12. Anonim, (2009), Air dan air limbah - Bagian 16: Cara uji cadmium (Cd) secara Spektrofotometri Serapan Atom (SSA) nyala, SNI 6989.16: 2009

13. Said, N.I. dan Firly, (2005), Uji Performance Biofilter Anaerobik Unggun Tetap Menggunakan Media Biofilter Sarang Tawon untuk Pengolahan Air Limbah Rumah Potong Ayam, JA/ 1(3):289-303

14. Sanita S, Soemarno, Suharjono, (2013), Pengaruh Suhu dan $\mathrm{pH}$ terhadap Laju pertumbuhan Lima Isolat Bakteri Anggota Genus Pseudomonas yang diisolasi dari Ekosistem Sungai Tercemar Deterjen di sekitar Kampus Universitas Brawijaya, JPAL. 3(2):58-62

15. Titiresmi, N. Sopiah, (2006). Teknologi biofilter untuk pengolahan limbah ammonia. J. Tek Ling 7(2): 173-179.

16. Michail K. M., G. T. Athanasia, S.A. Christos, C. Sandra, P. tavros, and V.V. Dimitrios, (2015), Molasses as an efficient low-cost carbon source for biological $\mathrm{Cr}(\mathrm{VI})$ removal, Journal of Hazardous Materials 281: 95-105

17. Reddy, S.M., Reddy, S. Ram, and Babu, G. Narendra., (2012), Basic Industrial
Biotechnology. Daryaganj, IND: New Age International, ProQuest ebrary. Web. 25 February 2016.

18. Brooks G F, et.al., (2001). Jawetz, Melnick, \& Adelberg's Medical Microbiology. $22^{\text {th }}$ Ed.New York: Lange Medical Books.

19. 17 Kulkarni, S.J and J.P. Kaware., (2014), Fixed Bed Removal of Heavy Metal-a Review, International Journal of Research (IJR). 1:861-171

20. 18. Nwabanne, J. T. and P.K., Igbokwe, (2012), Adsorption Performance of Packed Bed Column for the removal of Lead (II) using oil Palm Fibre, International Journal of Applied Science and Technology, 2(5):108117.

21. 19. Christian T-C., F. Henri, P. Catherine, Yuh-Shan Ho, (2005), Removal of lead (II) ions from synthetic and real effluents using immobilized Pinus sylvestris sawdust: Adsorption on a fixed-bed column, Journal of Hazardous Materials, B (123):135-144.

22. Brooks G F, et.al., (2001). Jawetz, Melnick, \& Adelberg's Medical Microbiology. $22^{\text {th }}$ Ed. New York: Lange Medical Books. 